Cezary Kosikowski

\title{
ROZUMIENIE CZASU W PRAWIE FINANSOWYM
}

\section{Prawo finansowe w czasie}

Czas pozwala określić m.in. powstanie i ewolucję instytucji finansowych (np. danin publicznych, pieniądza, banków, budżetu państwa itp.). Przy pomocy czasu, wyrażającego w epokach lub latach bądź miesiącach i dniach pewne okresy, możemy ustalić wystapienie określonych faktów (wydarzeń, dokumentów, aktów prawnych). Wskazują one na pojawienie się, a następnie zmiany lub zanikanie danych instytucji finansowych oraz ich prawnych regulacji. Czas jest w tym wypadku jedynie miara, przy pomocy której możemy ustalić, kiedy miały miejsce interesujące nas wydarzenia ustrojowe oraz społeczno-gospodarcze.

Sam czas, rozumiany jako pewien okres liczony przyjętymi jednostkami (godzinami, dobami, dniami, miesiącami, latami, epokami, erami itd.), nie jest miarą doskonałą dla określenia genezy i historii finansów publicznych i prawa finansowego. Nie możemy bowiem przyjąć z całą pewnościa, że w takiej to a takiej epoce lub w przedziale określonych lat, w każdym miejscu na świecie pojawiły się tożsame instytucje finansowe i ich regulacje prawne. Nie możemy tego stwierdzić w stosunku do czasów starożytnych, gdyż już wtedy cywilizacje europejskie (grecka, rzymska) i azjatyckie (chińska, japońska) oraz arabskie (egipska), ze względu na różny ich poziom oraz różnice kulturowe, wytworzyły odmienne rozwiązania w dziedzinie finansów publicznych. ${ }^{1}$ Nie inaczej stało się też w czasach nowożytnych. Poziom cywilizacyjny oraz rozwój społeczny był bowiem w jednych państwach bardziej zaawansowany niż w innych. Co więcej, niektóre państwa nawet dzisiaj nie zbliżyły się jeszcze swym poziomem do poziomu rozwiniętych cywilizacji w starożytności.

To nie czas jako taki, lecz inne czynniki kształtują rzeczywistość społeczną i gospodarczą oraz ustrojową. To pod ich wpływem w tym samym czasie fizycznym

Patrz szerzej Z. Fedorowicz, Instytucje finansowe, Warszawa 1965. 
w różnych miejscach na świecie obowiązywały lub obowiązują odmienne rozwiązania prawne dotyczące finansów publicznych. Miało i ma także miejsce zjawisko przenikania i recepcji niektórych rozwiązań prawnych pomiędzy różnymi państwami, a także zjawisko zanikania pewnych rozwiązań i zastępowania ich nowymi.

Przy pomocy czasu możemy jednak określić pewne etapy rozwojowe instytucji finansowych i prawa finansowego. Etapy te wyodrębnia się zwykle ze względu na dynamizm stosunków społecznych i gospodarczych oraz ustrojowych. Szczególnie istotnymi czynnikami kształtującymi rozwój społeczny są stosunki własnościowe oraz przyjęcie zasady wolności wszystkich ludzi, którzy stają się równi wobec prawa. W konsekwencji powyższego zmieniały się także funkcje i organizacja państwa. Wyłaniały się różne ustroje i formy sprawowania władzy publicznej. Z czasem powstały też bloki państw (militarne, gospodarcze, terytorialne). W tych warunkach musiały też powstawać nowe rozwiązania prawnofinansowe, właściwe dla danej sytuacji ustrojowej i społeczno-gospodarczej.

Genezy prawa odnoszącego się do publicznej gospodarki finansowej nie da się ustalić jedynie przez wskazanie faktów, dzięki którym powstał pieniądz, bądź pojawiła się danina publiczna lub zaczęto sporządzać budżet państwa. Nie oznaczało to bowiem jeszcze powstania regulacji prawnych, określonych z daty i nazwy aktów prawnych, poświęconych unormowaniu tych kwestii. Dzięki temu możemy wykluczyć twierdzenie, że prawo finansowe istnieje od czasu pojawienia się praw menniczych panującego lub od momentu wprowadzenia przez niego obowiązku wnoszenia przez poddanych na jego rzecz danin pieniężnych lub rzeczowych. Takie instytucje finansowe, jak pieniądz, danina (kontrybucja, opłata, podatek, akcyza), budżet państwa itp. pojawiły się wcześniej niż prawo normujące funkcjonowanie tych instytucji (prawo walutowe, daninowe czy budżetowe).

O powstaniu prawa finansowego można mówić dopiero wówczas, gdy społeczeństwo lub przynajmniej jego większość stała się podmiotem prawa publicznego. Musiało więc dojść do zmiany relacji: „władca - poddany” na relację: „państwo - obywatel". Emancypacja prawa finansowego nastapiła stosunkowo późno, gdy uregulowanie uprawnień i obowiązków w dziedzinie finansów publicznych nie mogło już ograniczać się do normowania zasad konstytucyjnych i gdy swymi rozmiarami zaczęło przekraczać przepisy określające działalność administracji publicznej w dziedzinie finansów publicznych.

Zasadniczy wpływ na pojmowanie i zakres prawa finansowego ma ustrój polityczny, w tym ustrój społeczno-gospodarczy. Wynika to z faktu, iż ten dział prawa odnosi się do publicznej działalności finansowej, której zakres jest różny w warunkach gospodarki rynkowej i gospodarki sterowanej dyrektywnie przez państwo.

Pierwsze stulecie gospodarki rynkowej, przypadające na lata 1850-1950, to czas, w którym dokonywały się zmiany w zakresie funkcji państwa i zakresu jego 
zadań. Początkowym wyzwaniom, jakie stawały przed XIX-wiecznym państwem i które dotyczyły głównie sprawności wewnętrznej funkcjonowania państwa (administracji i sądów) oraz bezpieczeństwa zewnętrznego, nie towarzyszyły na ogół inne zadania. Skromny był wówczas zakres wydatków publicznych na oświatę, ochronę zdrowia i naukę oraz rozwój infrastruktury komunalnej. Dlatego też ówczesna skarbowość obejmowała przede wszystkim procesy gromadzenia dochodów publicznych przeznaczonych na finansowanie wydatków publicznych związanych z funkcjonowaniem władzy. Sytuacja uległa zmianie już w latach 20- i 30-tych XX w. Stało się jasnym, że wzrost wydatków publicznych jest nieodwracalny. Pojawiły się więc problemy budżetowe dotyczące równowagi budżetowej, deficytu budżetowego i finansowania długów państwowych. $Z$ czasem krag zainteresowania poszerzył się o problematykę banku emisyjnego, a przez to pośrednio objął też zagadnienia walutowe.

Po II wojnie światowej w państwach o gospodarce rynkowej dalsze pojmowanie prawa skarbowego początkowo nie uległo zmianie, natomiast zmieniły się proporcje zainteresowania poszczególnymi instytucjami finansowymi. Głównym problemem stało się finansowanie wydatków publicznych. Rozwiązania tego problemu nie poszukiwano już tylko w doskonaleniu systemu dochodów publicznych, lecz w racjonalizacji planowania finansowego i w zwiększaniu efektywności wydatków publicznych. To na tym tle doszło też do rewizji poglądów na temat konieczności zachowywania rocznej równowagi budżetowej. Odejście od tej zasady spowodowało wzrost zainteresowania problematyką deficytu budżetowego oraz źródeł jego finansowania. W zaniku znalazły się natomiast zagadnienia finansowe monopoli fiskalnych oraz przedsiębiorstw publicznych. Nauka finansów publicznych zarzuciła problematykę publicznego prawa bankowego oraz prawa walutowego. $\mathrm{Z}$ ram prawa finansowego wydzieliła się też problematyka finansowania ubezpieczeń społecznych oraz zagadnienia prawa celnego. Krag zainteresowania poszerzył się z kolei o problematykę finansów międzynarodowych. Po powstaniu Wspólnot Europejskich wyłoniło się zaś odrębne wspólnotowe prawo finansowe, które obecnie funkcjonuje jako prawo Unii Europejskiej.

Inaczej potoczyły się losy finansów publicznych i prawa finansowego w b. państwach socjalistycznych. Kształtowały się one pod przemożnym wpływem rozwiązań wykształconych i przyjętych w Związku Radzieckim, pierwszym państwie socjalistycznym na świecie. W niewielkim stopniu i tylko w niektórych państwach socjalistycznych (Chiny, Polska) zakres finansów publicznych i prawa finansowego był częściowo różny od tego wzorca. Jedynie w socjalistycznej Jugosławii przyjęto zupełnie odrębny model gospodarczy i finansowy państwa.

W końcu lat osiemdziesiatych XX w., najpierw w Polsce, a potem w innych europejskich państwach socjalistycznych, doszło do upadku ich dotychczasowego 
ustroju. Tym samym straciło swoją aktualność tzw. socjalistyczne prawo finansowe. B. państwa socjalistyczne wybrały ustrój demokratyczny i gospodarkę rynkową. Po pewnym czasie zintegrowały się też gospodarczo i finansowo z państwami Europy Zachodniej, stając się członkami Unii Europejskiej. Powstało nowe prawo finansowe i to zarówno w wymiarze krajowym, jak i wspólnotowym. Nie sprawił tego sam czas, lecz bieg wydarzeń historycznych, powstałych w wyniku zachodzących przemian ustrojowych, społecznych i gospodarczych. W tym zakresie możemy zatem mówić raczej o prawie w czasie niż o czasie w prawie.

\section{Czas w planowaniu i sprawozdawczości finansowej}

Kategoria finansów publicznych opiera się na wyodrębnieniu wydatków i dochodów publicznych. Tylko w czasie, w którym wydatki publiczne nie występowały w sposób stały i nie miały zbyt szerokiego zakresu, możliwe było ich finansowanie w naturze lub w pieniądzu w ramach kontrybucji wojennych lub ówczesnych danin publicznych. Wtedy nie było jeszcze potrzeby planowania dochodów ani też kontrolowania ich zużycia, ponieważ fakt ten oceniano po efektach, np. po wygranej lub przegranej wojnie lub po skutecznej lub nieskutecznej obronie bądź udanej lub nieudanej wyprawie kolonizacyjnej itp. $Z$ czasem jednak zakres wydatków publicznych uległ rozszerzeniu i nabrał cech trwałości. Trzeba było zatem na stale wprowadzić pewne obowiązki daninowe.

Powstanie skarbu państwa (publicznego) przesądziło zaś zarówno o potrzebie kontroli zużywania środków publicznych, jak i o obowiązku składania z tego sprawozdań. Pierwsze spisy sporządzane w tym celu przez królewskich urzędników stały się jednocześnie zaczątkiem planowania finansowego w formie przyszłego budżetu państwa. Mimo iż historia zna kilka przykładów sporządzania takich zestawień przyszłych dochodów i wydatków publicznych, to jednak na stałe planowanie budżetowe pojawiło się dopiero w XIX w. i to nie wszędzie w tym samym czasie. W takim charakterze utrwaliła się też kontrola i sprawozdawczość budżetowa.

Planowanie finansowe ma przede wszystkim znaczenie ekonomiczne i organizacyjne. Dlatego też musi być osadzone w pewnym wycinku czasu. Wybór tego ostatniego jest sprawą racjonalnej konwencji. Musi ona uwzględniać fakt, że planowanie zawsze dotyczy przyszłości, natomiast przedmiot planowania finansowego (dochody i wydatki publiczne oraz ew. deficyt i dług publiczny) nie zawsze kształtuje się w sposób w pełni przewidywalny i pożądany. Im okres planowania jest krótszy, tym przewidywalność przyszłości jest łatwiejsza i bezpieczniejsza. Nie można jednak okresu planowania finansowego skracać do absurdu, przynajmniej nie jest to wskazane w skali makroekonomicznej. Koszty planowania oraz organizacja tego procesu przemawia za tym, aby okres makroekonomicznego planowania finansowe- 
go nie był krótszy niż jeden rok (niekoniecznie pokrywający się z rokiem kalendarzowym).

O wyborze horyzontu czasowego w makroekonomicznym planowaniu finansowym decydują bardzo różne czynniki i względy. Zależy to m.in. od tego o jaki rodzaj planu chodzi, a także od tego, jaki jest charakter prawny planu oraz jego znaczenie ustrojowe. Nie mniej istotnym jest także $i$ to, czy jest to jedyny plan finansowy w państwie, czy raczej jeden z wielu planów, które tworzą pewien system planów finansowych. Nie bez znaczenia są również funkcje ekonomiczne i ustrojowe określonego typu planów finansowych. Przy wyborze okresu planowania finansowego trzeba liczyć się także z koniecznością przyjęcia takiego samego dystansu czasowego dla określenia zobowiązań finansowych obywateli i jednostek organizacyjnych wobec państwa (dochody publiczne) i państwa wobec tych podmiotów (wydatki publiczne).

Nie można przy tym pominąć skutków braku równowagi budżetowej oraz występowania deficytu oraz długu publicznego w państwie. Od wystąpienia światowego kryzysu gospodarczego na przełomie lat 20-i 30-tych XX w. oraz pod wpływem teorii Keynesa przyjmuje się jednak, że roczny okres planowania nie jest dobrym miernikiem, jeśli zważyć na cykliczność gospodarki i związane z tym fazy, które ze względu na swoje właściwości wymagają stosowania zróżnicowanej polityki państwa. Od skuteczności tej polityki zależy czas trwania poszczególnych faz cyklu koniunkturalnego w danym państwie. W rocznym budżecie państwa należy więc wyrażać jedynie fragment określonej polityki, która dotyczy danego cyklu koniunkturalnego.

Jeśli plan finansowy ma być podstawą gospodarki finansowej państwa, to trzeba liczyć się z potrzebą nadania mu charakteru dyrektywnego (co najmniej po stronie wydatków publicznych). Następuje to poprzez nadanie planowi finansowemu wybranej formy prawnej i normatywne określenie procedury jego tworzenia, wykonywania, kontroli i sprawozdawczości oraz przyjęcie form prawnych odpowiedzialności związanej z tymi obowiązkami. Taka sytuacja odnosi się do planu finansowego państwa, zwanego budżetem państwa. Znajduje ona prawne unormowanie w konstytucjach państwowych oraz w aktach kodyfikujących tzw. prawo budżetowe. ${ }^{2}$

Poczynając jeszcze od konstytucji z XVIII w., poprzez konstytucje XIX i XX w., zasadą stała się roczność budżetu państwa. Zasada roczności budżetu państwa obowiązuje nadal, mimo iż współcześnie nie ma uzasadnienia ekonomicznego. Stan dzisiejszej nauki i techniki pozwala projektować przyszłość w perspektywie znacznie dłuższej niż jeden rok. Jedynym argumentem natury ekonomicznej jest dynami- 
ka gospodarki i zmienność inflacji pieniądza, w którym wyraża się wielkości dochodów i wydatków budżetowych. Natomiast za utrzymaniem rocznego okresu obowiązywania budżetu państwa przemawiają przede wszystkim względy ustrojowe, związane z płynnością rządów i potrzebą oceny ich działalności budżetowej w krótkich okresach czasu.

Rok kalendarzowy jest najczęściej wybieranym okresem dla roku budżetowego. Przyjmuje się jednakże także inne rozwiązania. Dość często rok budżetowy liczy się bowiem od 1 kwietnia do 31 marca (tak było również w Polsce do 1949 r.) albo od 1 lipca do 30 czerwca następnego roku kalendarzowego (tak jest np. w USA). Wybór tych terminów jest związany z tzw. rokiem gospodarczym, który zwłaszcza w rolnictwie wiąże się przecież z warunkami wegetacyjnymi roślin uprawnych. Występują też rozwiązania, które nie są związane z tymi okolicznościami, lecz z datami dotyczącymi ważnych dla danego kraju wydarzeń. Ustalenie roku budżetowego ma kapitalne znaczenie dla systemu statystyki i sprawozdawczości, a więc przekracza ramy samego planowania budżetowego.

Roczność budżetu państwa jest zasadą konstytucyjną. Oznacza to, że: 1) istnieje nakaz corocznego opracowywania i uchwalania ustawy budżetowej (zwanej również ustawą finansową lub skarbowa); 2) ustawy budżetowej nie można uchwalić na okres krótszy ani dłuższy od roku kalendarzowego, którego dotyczy rok budżetowy, z wyjątkiem ustawy o prowizorium budżetowym, która ze swej natury ma zastępować ustawę budżetową do czasu jej uchwalenia; 3) ustawa budżetowa obowiązuje zawsze od pierwszego dnia danego roku budżetowego, niezależnie od tego, kiedy została uchwalona i ogłoszona oraz niezależnie od tego, czy jej uchwalenie nie było poprzedzone zastosowaniem instytucji prowizorium budżetowego; 4) ustawa budżetowa obowiązuje nie dłużej niż do ostatniego dnia danego roku budżetowego i nie wymaga oznaczenia faktu swej derogacji; 5) wejście w życie, obowiązywanie i derogacja ustawy budżetowej na dany rok są niezależne od upływu kadencji i zmiany organów władzy ustawodawczej i wykonawczej państwa; 6) ustawa budżetowa na dany rok nie może być uchylona, można ją natomiast nowelizować w toku jej wykonywania (tzn. w ciagu roku budżetowego, którego ona dotyczy); 7) upływ roku budżetowego, którego dotyczyła ustawa budżetowa, nie stanowi przeszkody dla podjęcia czynności dotyczących kontroli i oceny jej wykonania (kontrola i sprawozdawczość budżetowa) oraz uruchomienia związanych z tym reguł odpowiedzialności rządu za wykonanie ustawy budżetowej.

Konsekwencją roczności budżetu państwa jest także i to, że plany finansowe wszystkich jednostek sektora finansów publicznych sporządza się także na okresy roczne i za takie też składa się sprawozdania z ich wykonania. Natomiast niedogodności roczności obowiązywania planów finansowych są częściowo niwelowane poprzez ustanawianie dopuszczalnych wyjątków. W budżecie państwa dotyczą one do- 
puszczalności niewygasania niektórych wydatków budżetowych lub planowania na okresy wieloletnie niektórych programów lub inwestycji. Natomiast w planowaniu finansowym pozabudżetowych funduszy celowych zasadą jest przechodzenie środków finansowych nie wykorzystanych w danym roku na rok następny.

O tym, że roczny okres planowania nie jest dogodny dla finansów publicznych, przekonano się już dawno. Finanse publiczne nie stanowią bowiem wartości samych w sobie. Mają natomiast służyć realizacji programów społecznych i gospodarczych, które z natury rzeczy sporządza się na okresy dłuższe niż rok. Programy takie zawierają przede wszystkim wskazanie celów i zadań, które powinny być osiagnięte w zamierzonym czasie. Wskazaniom tym muszą towarzyszyć również szacunkowe określenia wysokości i rodzajów środków, jakie są potrzebne dla realizacji założonych programów. Dlatego też od pewnego czasu zaczęto podejmować różnego rodzaju próby wydłużenia horyzontu czasowego w planowaniu finansowym. Wyłonił się jednak dylemat, w jaki sposób planować finanse publiczne na okresy dłuższe niż rok, a zwłaszcza czy wydłużyć czas obowiązywania ustawy budżetowej, czy też wprowadzić inne urządzenie planistyczne w finansach publicznych. W praktyce pojawiły się różne rozwiązania.

Najpierw odnotować trzeba mniej lub bardziej udane próby racjonalizacji wydatków publicznych, które zapoczątkowano w USA w 1965 r., wprowadzając metodę Planning-Programming-Budgetinig System (PPBS). Później próbowano metody zarządzania poprzez cele (management by objectives). We Francji zastosowano z kolei metodę racjonalizacji wyborów budżetowych (rationalisation des choix budgetaires). Natomiast brytyjska odmiana PPBS nazwana została output budgeting, a potem występowała jako Program Analysis and Rewiew. W nauce ocenia się, że wszystkie wymienione metody mają wiele wspólnych cech. ${ }^{3}$ Należy do nich to, że: 1) za podstawę prac planistycznych przyjmuje się wyznaczanie celów (programów), 2) obowiązek badania racjonalności wydatków jest określony prawnie, 3) analizy opierają się na porównywalnych kryteriach oceny, 4) programy mają być realizowane niezależnie od ograniczeń wynikających z rocznego okresu planowania budżetowego, 5) realizacja programów pozwala przełamać bariery resortowej organizacji administracji, 6) racjonalizacja wyborów zakłada permanentne badanie racjonalności wcześniej podjętych decyzji, 7) przedmiotem analizy i wyboru są najważniejsze potrzeby, nie zaś te, które wynikają z przeszłości, 8) całościowe określenie kosztów umożliwia eliminację marnotrawstwa środków. Wszędzie tam, gdzie próbowano powyższych metod racjonalizacji wydatków publicznych, nie doszło do wydłużenia dotychczasowego okresu planowania budżetowego ani też nie powstał żaden inny wieloletni plan finansowy państwa. 
Od pewnego czasu podejmuje się inne próby wydłużenia okresu planowania finansów publicznych. Są one związane z tzw. zadaniowym planowaniem budżetowym. Jest to nowoczesna metoda zarządzania środkami publicznymi poprzez cele odpowiednio skonkretyzowane i zhierarchizowane na rzecz osiagania określonych rezultatów, czyli realizacji zadań, mierzonych za pomocą ustalonego systemu mierników. ${ }^{4}$ Budżet zadaniowy stanowi instytucję, która znalazła zastosowanie i sprawdziła się w praktyce wielu państw, a w innych jest ona próbowana. Przewiduje ją także prawo polskie. ${ }^{5}$ Wszędzie tam, gdzie zdecydowano się na stosowanie zadaniowego planowania budżetowego, przewiduje się wydłużenie planowania budżetowego do dwóch lub trzech lat, przy czym ustawę budżetową uchwala się co roku, dokonując w niej korekt dotyczących lat następnych.

W Polsce wprowadzono od 2010 r. jednocześnie Wieloletni Plan Finansowy Państwa (WPFP), który de facto stanowi raczej 4-letni budżet państwa niemający jednakże charakteru dyrektywnego, ponieważ jego ustalenia podlegają obowiązkowym korektom w związku z uchwaleniem rocznej ustawy budżetowej. Rozwiązania prawne dotyczące budżetu zadaniowego ${ }^{6}$ i WPFP w Polsce maja jednak bardzo poważne wady. ${ }^{7}$

Najlepiej kwestia czasokresu planowania finansowego została rozwiązana w Unii Europejskiej. Już w 1970 r. postanowiono tam przejść do kilkuletniego planowania finansowego. Najpierw zobowiązano Komisję do corocznego przygotowywania prognozy finansowej na trzy następne lata budżetowe. Gdy zaś od 2000 r. zaczęto uchwalać średniookresowe programy społeczno-gospodarcze (Agenda 2000 na lata 2000-2006, Nowa Perspektywa Finansowa na lata 2007-2013), stało się jasnym, że roczny budżet ogólny UE może być tylko wycinkiem ustaleń dokonywanych na dłuższy okres. Doszło więc do stworzenia podstaw prawnych wieloletniego planowania finansowego (tzw. ram finansowych). ${ }^{8}$ Przewiduje się coroczne dostosowanie ram finansowych, ale tylko w odniesieniu do aktualizacji wyceny i obliczenia marginesu dostępnego w ramach pułapu dochodów własnych. Pozostałe elementy średnioterminowego planu finansowego UE mają charakter dyrektywny i obowiązują w toku prac nad rocznym budżetem ogólnym UE. ${ }^{9}$ Sądzę, że to rozwiązanie powinno być obowiązującym w planowaniu finansowym państw członkowskich UE. Patrz szerzej Budżet zadaniowy w Polsce. Reorientacj
mi, pod red. T. Lubińskiej, Warszawa 2007, s. 17 i n. 


\section{Czas w gromadzeniu dochodów publicznych i dokonywaniu wydatków publicznych}

Gromadzenie dochodów publicznych i dokonywanie wydatków publicznych odbywa się na podstawie przepisów ustaw daninowych i ustaw wskazujących na poszczególne rodzaje wydatków publicznych. Czynnik czasu jest także obecny wtedy, gdy chodzi o ustalenie daty wejścia i obowiązywania danej ustawy daninowej lub ustawy stanowiącej podstawę prawną zobowiązania państwa do wypłaty świadczenia stanowiącego wydatek publiczny. W tym zakresie obowiązuje zasada lex retro non agit, chyba że wejście ustawy z mocą wsteczną jest korzystniejsze dla podmiotów biernych lub wręcz z taką myślą zostało ono wprowadzone.

Przepisy prawne określają nie tylko zakres podmiotowy i przedmiotowy obowiązków i uprawnień prawnofinansowych podmiotów czynnych i biernych. Normują także zagadnienia dotyczące czasu właściwego dla powstania, wykonywania oraz ustania obowiązków i zobowiązań daninowych lub obowiązków i roszczeń do uzyskania świadczeń stanowiących wydatki publiczne.

Zawsze bowiem regulacje prawne związane z czynnikiem czasu wiążą się z potrzebą normatywnego ustalenia: 1) w jakim czasie powstaje, istnieje i ustaje obowiązek lub zobowiązanie daninowe bądź uprawnienie do świadczenia pieniężnego stanowiącego wydatek publiczny; 2) jak ustala się czas, którego dotyczy wymiar zobowiązania daninowego lub zobowiązania dotyczącego wypłaty świadczeń objętych wydatkami publicznymi oraz terminy ich płatności; 3) w jakim czasie powinno dojść do ustalenia istnienia obowiązku i konkretyzacji (wymiaru) zobowiązania daninowego lub obowiązku wypłaty świadczenia stanowiącego wydatek publiczny i konkretyzacji jego wysokości oraz jakie są terminy przedawnienia wymiaru; 4) w jakim czasie należy wykonać zobowiązanie daninowe lub zobowiązanie dotyczące wypłaty świadczenia objętego wydatkiem publicznym oraz 5) jakie są konsekwencje prawne przekroczenia wyznaczonych terminów, w tym terminów przedawnienia wykonania lub egzekucji przymusowej zobowiązania; 6) zasad stosowania, obliczania oraz skracania, wydłużania, odraczania i przywracania terminów określonych w ustawach daninowych lub w ordynacji podatkowej.

W odniesieniu do dochodów publicznych gromadzonych jako świadczenia bezzwrotne normatywnych ustaleń związanych z czasem najczęściej dokonuje się w akcie prawnym kodyfikującym przepisy prawa zobowiązań podatkowych i postępowania podatkowego (tzw. ordynacja podatkowa). Pewne wyjątki od tych ustaleń regulują natomiast poszczególne ustawy daninowe. Dzięki temu regulacje prawne dotyczące różnych aspektów czasu w prawie daninowym ${ }^{10}$ kształtują się w miarę

10 Patrz szerzej A. Nita, Czynnik czasu w prawie podatkowym. Studium z dziedziny zobowiązań podatkowych, Gdańsk 2007. 
jednolicie. Natomiast w odniesieniu do dochodów publicznych gromadzonych jako świadczenia zwrotne lub świadczenia stanowiące pomoc ze źródeł zagranicznych obowiązują inne ustalenia dotyczące terminów. Wynikają one na ogół z postanowień odpowiednich umów, na mocy których są osiagane owe dochody.

Podstawą ustaleń związanych z czasem powstania, istnienia i ustania obowiązków daninowych jest posługiwanie się dwoma odrębnymi pojęciami normatywnymi, tj. obowiązku podatkowego i zobowiązania podatkowego. Obowiązkiem podatkowym jest wynikająca $z$ ustaw podatkowych nieskonkretyzowana powinność przymusowego świadczenia pieniężnego w związku z zaistnieniem zdarzenia określonego $w$ tych ustawach. Natomiast zobowiązaniem podatkowym jest wynikające $\mathrm{z}$ obowiązku podatkowego zobowiązanie podatnika do zapłacenia podatku w wysokości, w terminie oraz w miejscu określonych w przepisach prawa podatkowego. Natomiast w doktrynie wymienia się liczne różnice dotyczące pojmowania obowiązku i zobowiązania podatkowego. ${ }^{11}$

Jedna $\mathrm{z}$ nich polega na tym, że obowiązek podatkowy powstaje z mocy ustawy, która może jednocześnie wskazywać na wysokość zobowiązania podatkowego lub nakładać na podatnika obowiązek obliczenia tej wysokości. Takie zobowiązanie powstaje $\mathrm{z}$ dniem zaistnienia zdarzenia, $\mathrm{z}$ którym ustawa podatkowa wiąże powstanie takiego zobowiązania. Nie zachodzi wówczas konieczność konkretyzacji zobowiązania podatkowego $\mathrm{w}$ formie decyzji organu podatkowego, chyba że podatnik nie podjął obowiązku podatkowego lub wykonał go w sposób niepełny. Wówczas organ podatkowy musi w drodze decyzji określić wysokość zobowiązania podatkowego. Czasami jednak ustawy podatkowe przewidują konieczność skonkretyzowania obowiązku podatkowego $\mathrm{w}$ formie zobowiązania podatkowego, które powstaje $\mathrm{z}$ dniem doręczenia decyzji organu podatkowego, ustalającej wysokość tego zobowiązania. Wyróżnione wyżej dwa sposoby powstawania zobowiązań podatkowych oraz dwa rodzaje decyzji podatkowych ich dotyczących (decyzje określające i decyzje ustalające) różnią się zatem tym, że ordynacja podatkowa wskazuje na różny czas powstawania, istnienia i ustania zobowiązań podatkowych. Fakt ten nie zawsze jest znany podatnikom, a często niestety nie jest też prawidłowo interpretowany przez organy orzekające (organy podatkowe, sąd administracyjny).

Prawo daninowe posługuje się też instytucją przedawnienia. Dotyczy ona przedawnienia prawa do ustalenia zobowiązania podatkowego, jak i prawa przedawnienia płatności zobowiązania podatkowego. W pierwszym wypadku zobowiązanie nie powstaje, a w drugim przestaje być wymagalne i powoduje ustanie stosunku zobowiązaniowego. Ustawodawca wybiera zwykle krótszy termin przedawnienia prawa do ustalania zobowiązania i dłuższy termin przedawnienia płatności zobowią- 
zania podatkowego. W jednym i drugim wypadku terminy te podlegają wydłużeniu na skutek ustawowego zawieszenia ich biegu ze względu na pewne okoliczności. Wśród tych ostatnich są m.in. podjęte czynności prawne przez organy podatkowe lub sąd. W rezultacie zobowiązania daninowe są niekiedy realizowane dopiero po upływie kilku lub nawet kilkunastu latach, co godzi w zasadę roczności ich planowania.

Zobowiązania daninowe ustala się w oparciu o zasadę roku podatkowego, pokrywającego się z rokiem kalendarzowym, chyba że niektóre ustawy daninowe stanowią inaczej. Oznacza to, że byt zobowiązania podatkowego wiąże się zawsze $\mathrm{z}$ rokiem, w którym wystąpiło zdarzenie, z którym ustawa wiąże powstanie zobowiązania lub w którym doręczono decyzję organu podatkowego ustalającą lub określającą wysokość zobowiązania. Ustawy daninowe mogą jednak przewidywać wyjątki od tej reguły. Mogą bowiem przyjmować, że zobowiązanie powstaje w roku następnym od roku, w którym wystąpiło zdarzenie podatkowe. Mogą też posługiwać się tzw. rokiem obrotowym, co jest niekiedy uzasadnione, chociaż prowadzi też do pewnego zaciemnienia obrazu realizacji dochodów publicznych w skali roku kalendarzowego, według którego planuje się dochody publiczne i ujmuje się je w statystyce publicznej.

Ustawy daninowe określają również terminy płatności zobowiązań lub ich zwrotu, gdy są pobrane bezzasadnie lub w nadmiernej wysokości (nadpłaty). Terminy te są na ogół różne ze względu na rodzaj zobowiązania i sposób jego powstania. Ustawa może przewidywać możliwość zawieszenia biegu terminów lub ich modyfikacji przez organy podatkowe. Terminy płatności ustala się jako jednorazowe lub zaliczkowe. Terminy płatności mogą być zatem ustalone w różnych jednostkach czasu (dniach, dekadach, miesiącach, kwartałach, rocznie) ze wskazaniem konkretnych dat oraz z uwzględnieniem pewnych wyłączeń (np. świąt i dni wolnych od pracy).

Niezbędne jest jednolite określenie zasad obliczania terminów obowiązujących w prawie daninowym, jak również ich skracania, wydłużania, odraczania i przywracania. Następuje to zwykle w przepisach ordynacji podatkowej.

Konsekwencje prawne niedotrzymania terminów wyznaczonych dla wykonania obowiązków i zobowiązań podatkowych mogą być różne. Ustawy przewidują bowiem jednoczesną możliwość stosowania kilku rodzajów sankcji podatkowych i karnych skarbowych. Nie chodzi zatem tylko o możliwość zastosowania przymusowej egzekucji zobowiązań podatkowych, lecz także o sankcje w postaci zapłacenia odsetek za zwłokę oraz o możliwość utraty pewnych przywilejów podatkowych (np. prawa do potrącenia podatku należnego, prawa do ryczałtowej lub uproszczonej formy opodatkowania, prawa do ulgi lub zwolnienia podatkowego, prawa do umorzenia, odroczenia lub rozłożenia na raty płatności). 
W odniesieniu do czynności polegających na dokonywaniu wydatków publicznych obowiązują inne reguły związane z czasem realizacji tego procesu. Inna jest przede wszystkim natura ekonomiczna i prawna dochodów i wydatków publicznych oraz samych czynności ich gromadzenia i wydatkowania. Te ostatnie dotyczą realizacji przez państwo zobowiązań wynikających z planów finansowych, a powstałych na podstawie ustaw lub umów (cywilnoprawnych, publicznoprawnych, umów o pracę itp.). To na państwie, reprezentowanym przez odpowiednie jego organy $i$ instytucje, spoczywa obowiązek dokonania wypłaty stosownych świadczeń, stanowiących wydatki publiczne.

Ponadto ma znaczenie to, jaki charakter prawny ma dany rodzaj wydatku publicznego oraz z jakiego źródła jest on dokonywany. Jeśli przyjmiemy, że wydatki publiczne mogą mieć formę konsumpcji zbiorowej i indywidualnej, to w odniesieniu do każdej z tych form stosuje się inne reguły czasowe.

Wydatki na finansowanie konsumpcji zbiorowej są ujęte w budżecie państwa lub w budżetach jednostek samorządu terytorialnego bądź w innych planach finansowych jednostek sektora finansów publicznych. W tym zakresie stosuje się do nich zasadę roczności, natomiast terminy ponoszenia wydatków wynikają z określonego mechanizmu finansowania (innego w wykonywaniu budżetów i pozostałych planów finansowych). Ustala je zwykle akt prawny kodyfikujący przepisy o finansach publicznych.

Inaczej jest z finansowaniem wydatków konsumpcji indywidualnej. Dotyczą one świadczeń opartych na bardzo różnych tytułach prawnych i dokonywanych w odrębnych formach prawnych. Wśród nich są bowiem świadczenia dotyczące: zapłaty za dostawy, roboty i usługi; wynagrodzenia, nagrody, zasiłki, stypendia; odszkodowania i rekompensaty oraz świadczenia wynikające z wyroków sądowych; spłaty kredytów i pożyczek oraz innych zobowiązań umownych; subwencji lub gwarantowanych prawnie dotacji budżetowych. Wysokość tych świadczeń jest skonkretyzowana i wynika $\mathrm{z}$ umowy lub decyzji administracyjnej bądź z wyroku sądowego. Wszelkie terminy dotyczące owych świadczeń, w tym zarówno terminy dotyczące powstania, istnienia, wykonania, egzekucji i ustania oraz przedawnienia wynikających stąd zobowiązań, wynikają w większości z postanowień umów, a w niektórych sytuacjach są określone również przepisami ustaw. Są to najczęściej ustawy spoza kręgu ustaw finansowych. Mogą to być również terminy ustalane przez właściwy organ lub sąd. Ustalanie wysokości świadczeń, jak i ich realizacja i egzekucja ma bowiem miejsce poza organami administracji finansowej ( $\mathrm{z}$ wyjątkiem spraw dotyczących subwencji i dotacji). 


\section{Czas a problem odpowiedzialności prawnofinansowej}

Odpowiedzialność w prawie finansowym ma kilka charakterystycznych cech. Po pierwsze, opiera się na różnego typu sankcjach, począwszy od sankcji ekonomicznych po sankcje prawne, określone w przepisach prawa finansowego oraz w przepisach innych działów prawa.

Po drugie, cechą charakterystyczną odpowiedzialności w prawie finansowym jest to, że jest ona odmienna w stosunku do podmiotów biernych i do podmiotów czynnych prawa finansowego, a nawet jest zróżnicowana (przedmiotowo i podmiotowo) w każdym z tych obrębów.

Odpowiedzialność podmiotów czynnych podmiotów czynnych może obejmować, odpowiednio do statusu podmiotu czynnego, odpowiedzialność konstytucyjną lub odpowiedzialnością karną organów zarządzających finansami publicznymi albo być odpowiedzialnością administracyjną i odszkodowawczą organów finansowych, bądź odpowiedzialnością służbową (pracowniczą) lub karną pracowników organów finansowych.

Natomiast odpowiedzialność prawna podmiotów biernych prawa finansowego może opierać się równocześnie na stosowaniu: 1) sankcji systemowych prawa finansowego, 2) sankcji wynikających z naruszenia dyscypliny finansów publicznych, 3) sankcji karnych oraz sankcji karnych skarbowych. Rzadziej natomiast wchodzą w grę sankcje administracyjne (np. stwierdzenie nieważności decyzji w postępowaniu podatkowym lub postępowaniu celnym) i sankcje cywilne (np. nieważność czynności prawnej niezgodnej z prawem), ponieważ mają one swe „odpowiedniki” w postaci sankcji finansowych (np. sankcji cywilnej w postaci obowiązku zwrotu nienależnego świadczenia pieniężnego lub niesłusznego wzbogacenia odpowiada sankcja finansowa w postaci obowiązku zwrotu dotacji budżetowej wykorzystanej na cele inne od tych, na którą udzielono dotacji).

Po trzecie, odpowiedzialność w prawie finansowym może być rezultatem zbiegu kilku ustaw określających odpowiedzialność tego samego podmiotu za ten sam czyn (zachowanie). Oznacza to, że w odniesieniu do podmiotów prawa finansowego odpowiedzialność jednego rodzaju (np. odpowiedzialności opartej na sankcjach systemowych) nie wyklucza odpowiedzialności innego rodzaju (np. odpowiedzialności karnej skarbowej). Zasada ta obowiązuje również w postępowaniu o naruszenie dyscypliny finansów publicznych, chociaż w tym zakresie przewiduje się pewne wyjątki, na mocy których prawomocne skazanie za przestępstwo stanowiące jednocześnie naruszenie dyscypliny finansów publicznych powoduje umorzenie postępowania w sprawie odpowiedzialności za naruszenie dyscypliny finansów publicznych. 
Po czwarte, w odpowiedzialności opartej na przepisach prawa finansowego w zasadzie nie występuje wina jako przesłanka odpowiedzialności. Czasami zastępuje ją inna przesłanka, jak np. umyślność lub nieumyślność bądź też podstawę odpowiedzialności stanowi obowiązek prawnofinansowy. Inaczej też ocenia się społeczne znaczenie zachowania stanowiącego podstawę odpowiedzialności, co przekłada się także na wybór sankcji lub jej rozmiary ilościowe. Generalnie jednak w odpowiedzialności w prawie finansowym jaskrawo widoczny jest wpływ zasady ochrony interesów fiskalnych państwa na zasięg i rozmiary odpowiedzialności.

Po piąte, nie ma jednolitej jurysdykcji i procedury postępowania w sprawach odpowiedzialności w prawie finansowym. Wynika to zresztą ze stosowania różnych rodzajów sankcji i na podstawie różnych ustaw. Nie jest zatem także jednolity zakres ochrony prawnej podmiotu odpowiedzialności.

Skoro przedmiotem odpowiedzialności są zachowania wyrażające stopień wykonywania kompetencji i obowiązków prawnych, to podstawowa linia podziału odpowiedzialności prawnej przebiega ze względu na podział podmiotów prawnych na podmioty bierne i podmioty czynne. Zakres ich uprawnień i obowiązków oraz cele, które prawodawca wiąże $\mathrm{z}$ ich wykonywaniem, są diametralnie różne. Nie można wobec tego stosować do nich w pełni identycznych form odpowiedzialności prawnej. Tym samym również rozwiązania prawne określające czas powstania, ustalania, istnienia, egzekucji i ustania odpowiedzialności prawnofinansowej podmiotów czynnych i biernych nie są tożsame. Decydują o tym przepisy ustaw stanowiących podstawę tej odpowiedzialności.

W zakresie odpowiedzialności dotyczącej podmiotów czynnych należą do nich przepisy ustaw ustrojowych, ${ }^{12} \mathrm{z}$ konstytucją państwową na czele, a także przepisy ustaw przewidujących odpowiedzialność funkcjonariuszy państwowych oraz pracowników służby cywilnej i pracowników samorządowych. Wchodzi także w grę odpowiedzialność pracownicza oparta na przepisach prawa pracy.

W odniesieniu do odpowiedzialności podmiotów biernych podstawy prawne tkwią w przepisach ordynacji podatkowej oraz w ustawie o finansach publicznych, a także w przepisach dotyczących odpowiedzialności za naruszenie dyscypliny finansów publicznych i odpowiedzialności karnej skarbowej. We wszystkich wymienionych aktach określono zasady i formy odpowiedzialności oraz terminy przedawnienia ścigania i wykonania sankcji.

Wspólną cechą tych jakże różnych rodzajów i form odpowiedzialności jest m.in. to, że finanse publiczne podlegają szczególnej i szerokiej ochronie prawnej. $\mathrm{W}$ czasie trwa ona długo, obejmując z reguły nie tylko okres kadencji lub nomina- 
cji funkcjonariusza bądź zatrudnienia pracownika, lecz także wykraczając poza ten czas (np. po upływie kadencji lub upadku rządu). Odpowiedzialność jest natomiast egzekwowana stosunkowo szybko. Wadą tej odpowiedzialności jest jednakże to, że nie zmierza ona przede wszystkim do zapewnienia prawidłowej realizacji kompetencji i zadań finansowych i wyeliminowania $\mathrm{z}$ tego procesu podmiotów, które nie są w stanie tego zapewnić lub nagminnie naruszają swoje obowiązki prawnofinansowe. 


\title{
TIME IN FINANCIAL LAW
}

\author{
SUMMARY
}

The article presents the importance of time in history of financial law as well as in creation and application of norms of financial law. In the history of public finance theory and financial law time is only a measure of political, social and economic events that affect appearing, modifications and disappearing of specific financial institutions.

Time is of crucial importance for financial planning. Financial plans are generally included in the annual plans. This results from using the concept of so-called financial year (budgetary year, fiscal year) for drafting, execution and control of execution of the financial plans. However, the modern financial economy requires a longer time horizon (so-called long-term planning), that is already applied by most of developed countries and European Union.

There are completely different aspects of time to consider when one discusses issues of generating of public revenues and public expenditures. The assessment of levy liability and of payments of public expenditures has to be determined by time frame. Otherwise, it could be possible neither to determine their extent nor to attribute to them any legal consequences like for example limitation of assessment or enforcement or sanctions (fines, interest for late payment) that are applied in cases of violation of legally binding deadlines. Time also affects factors responsible for the obligation's existence (for example the obligated or entitled person's age, period of conducting of economic or professional activities, or period of benefiting from tax privileges). On the other hand, a variety of time limits apply to financial proceedings.

At last, time plays very important role in the determination of various forms of liability under financial law, particularly because of the application of financial sanctions, differentiated based on economic and legal criteria.

Therefore, the main conclusion is that time must be determined in financial law precisely, in the manner that leaves no room for any doubt as to whether the norm regulating financial law rights and obligations is binding or not. Therefore, time cannot be presumed. 